\title{
'Being dialogic with the pragmatic literacies of late medieval England'
}

\author{
Elisabeth Salter
}

\begin{abstract}
This article uses last will and testaments from several regions of England as a major source of evidence for the ways that the majority of medieval people used written text in the formation of communities of interpretation. In so doing it examines encounters with texts that must have informed medieval people's understandings of the English language, including the nuances of meaning that English could provide in a society that was still employing Latin for many official communications. These encounters are understood to be dialogic in a number of ways and the author's interaction with the evidence of these encounters is also understood to be a dialogic process. A premise of this article is that an administrative document such as the last will and testament must be understood as a major source of contact with the written word for the non-elite people of late medieval England. This is an association with written text - both vernacular and Latin - described as 'pragmatic literacy' by Michael Clanchy in his formative work on the interactions between orality, literacy and memory in the high and late middle ages. A key proposition, therefore, is that if we are to understand more about the ways that the majority of people interacted with and interpreted 'English' (i.e. literature) in this era, then we need to consider administrative documents such as the last will and testament, and the uses of these pragmatic literatures.
\end{abstract}

\section{Article}

In this article I am using the last will and testaments from several regions of England as a major source of evidence for the ways that the majority of medieval people used 
written text in the formation of communities of interpretation. In doing so I am examining encounters with texts that must have informed medieval people's understandings of the English language, including the nuances of meaning that English could provide in a society that was still employing Latin for many official communications. I understand these encounters to be dialogic in a number of ways, which are examined throughout this article, and also I understand my interaction with the evidence of these encounters to be a dialogic process. I take a 'community of interpretation' to be a group of people who share an idea or set of beliefs. These may be formed on an ad hoc basis or according to more established conventions, for example through the modes of behaviour or belief expected by particular institutions. Communities of interpretation are central to the ways that (medieval) people formed their understandings of themselves, others and the world around them and this was in turn an important element in the formation and maintenance of socio-cultural bonds.

A premise of this article is that an administrative document such as the last will and testament must be understood as a major source of contact with the written word for the non-elite people of late medieval England. This is an association with written text - both vernacular and Latin - described as 'pragmatic literacy' by Michael Clanchy in his formative work on the interactions between orality, literacy and memory in the high and late middle ages. ${ }^{1}$ Therefore if we are to understand more about the ways that the majority of people interacted with and interpreted 'English'

\footnotetext{
${ }^{1}$ Michael T. Clanchy, From Memory to Written Record: England 1066-1377, $2^{\text {nd }}$ edition (Oxford: Blackwell, 1993); see also Pragmatic Literacy: East and West ed. by Richard Britnell (Rochester, NY: Boydell Press, 1997).
} 
(i.e. literature) in this era, then we need to consider administrative documents such as the last will and testament, and the uses of these pragmatic literatures.

Claiming that administrative documents were a key form of literary product for the masses in late medieval society may seem to indicate that this article will be rather distant from the examples of vernacular English medieval literature that are usually cited. Take for example the works of Geoffrey Chaucer, which are extraordinary, evocative and brilliant - they are also often on syllabi for GCSE and A Level English Literature, but they were relatively inaccessible to the masses in medieval England. The myth of Chaucer as the founding father of English was being invented at least from the fifteenth century when Lydgate announced that Chaucer 'Gan oure tonge firste to magnifie, /And adourne it with his eloquence'. ${ }^{2}$ And as Christopher Cannon has traced, despite a gap in interest in the sixteenth century, at least from the time of Dryden, there was a renewed preoccupation with claiming Chaucer as the founder of 'our old English'. ${ }^{3}$ In his 1998 work, The Making of Chaucer's English, Cannon carefully elucidates the 'myth of origin' that still enfolds Chaucer as a founder of English. He points out that it is the combination of novelty 'and subsequent effect' which encourages literary history to see origination in a specific writer (novelty without invention, he suggests is identified as 'eccentricity'). ${ }^{4}$

${ }^{2}$ Christopher Cannon, The Making of Chaucer's English: A Study of Words (Cambridge: Cambridge University Press, 1998), p. 179, citing Lydgate's The Troy Book (1412- 1420).

${ }^{3}$ Cannon, Making of Chaucer's English, p. 187, citing the 'Preface' to Dryden's Fables (1700).

${ }^{4}$ Cannon, Making of Chaucer's English, p. 180. 
Despite the relative inaccessibility of Geoffrey Chaucer's works to the medieval masses, we can use this literature as evidence for medieval vernacular vocabulary and language use: part of the greatness of Chaucer is the way that he appears to reach to the common person, narrating the raw pain and bawdy humour of everyday medieval life. The artful interplay between high style and a literary version of common speech is inherent in many of Chaucer's works and part of his play with ideas of social status and agency; the Canterbury Tales being an excellent example. Examples of the ways that Chaucer plays with the notion of common speech can be found in the dialogue between the Reeve and the Miller. The Reeve says:

Right in his cherles termes wol I speke I pray to God his nekke mote to-breke He kan wel in myn eye seen a stalke But in his owene he can nat seen a balke. ${ }^{5}$

So the Reeve refers to the common, 'cherles termes' of the Miller and then goes on to do his own scriptural translation or 'quotation' in the common tongue. Another good example is in the 'Tale of Melibee' where Melibeus's wife reasons with her husband and does so by rendering age-old wisdom (often explicitly the words of men) into common speech. Prudence refers to the common 'proverb' on multiple

\footnotetext{
${ }^{5}$ Geoffrey Chaucer, 'The Reeve's Prologue', The Canterbury Tales, The Riverside Chaucer, General Editor Larry D. Benson, Third Edition (Oxford: Oxford University Press, 1988), 11. 3917-3920 (p. 78).
} 
occasions. ${ }^{6}$ Another way of thinking about Prudence's references and their function is to see Prudence as stirring Melibeus's memory in order to appeal to common sense which is the point of common speech - speaking in a way that makes sense in an everyday meaningful way. ${ }^{7}$ In her analysis of the place of Boethian thought in the medieval imagination, Sarah McKeon extends the consideration of the writings of Chaucer (and his contemporary John Gower) to appreciate the ways that these writers contributed to contemporary debates about the formation of understanding. In so doing, McKeon proposes, these writers demonstrate their confidence in the ability of vernacular languages (in their case English) to convey truth (or reality). McKeon identifies the ways that, during the late fourteenth century, the vernacular word itself grew in strength as a means for philosophical thinking about the process of making meaning and the construction of communities of interpretation. Through his translation of Boethius's Consolation of Philosophy (the Boece), for example, as well as other works such as the Canterbury Tales, McKeon shows how Chaucer used ideas of plain speech and the common tongue to re-evaluate literary conventions in the 'realist paradigm of late medieval England', and she demonstrates the dialogic processes of interpretation that occur in the interstices of "writer, reader and individual intellect' ${ }^{8}$ Cannon also examines the ways that literary patterns and tropes employed by Chaucer (and his contemporaries such as William Langland), are

${ }^{6}$ See Chaucer, 'The Tale of Melibee', Canterbury Tales, Riverside Chaucer, ll. 10489, 1214-15 (pp. 219, 224).

${ }^{7}$ I am grateful to Dr Sarah McKeon for these references.

${ }^{8}$ Sarah McKeon, ““(T)he blake cloude of errour”: poetry, philosophy, and the Boethian aesthetic in the late fourteenth century' (Unpublished PhD. Thesis, Aberystwyth University, 2014), pp. 225-229. 
influenced by medieval schooling. For example he identifies the ways that the use of what seem like common (proverbial) sayings by these writers is informed by medieval educational texts, such as the Distichs of Cato or Alan de Lille's Liber Parabolurm. Cannon describes the result as a 'poetics of patchwork' in which the use and translation of these sayings is so instinctive to the writer that citation seems unnecessary to them (and indeed to the medieval reader also educated by the same means) ${ }^{9}$

Some of what appears to be proverbial, that is common speech, in the works of late fourteenth century writers such as Chaucer is, as Cannon has shown, directly drawn from the texts digested by these writers as 'schoolboy poets'. ${ }^{10}$ Lexicographers and historians are in debate about the extent that actual medieval speech is identifiable in Chaucer's literary version of speech. Cannon proposes that, 'a spoken history will necessarily result in the failure of the written record'. ${ }^{11}$ At the same time, however, he admits that the lack of a history for a given word may also be evidence for the loss of written forms. ${ }^{12}$ The works of late medieval (canonical) writers such as Chaucer therefore give us special access to forms of common speech and vernacular practice (and ways of making meaning) that may have been in use by real medieval people.

\footnotetext{
${ }^{9}$ Christopher Cannon, From Literacy to Literature: England 1300-1400 (Oxford: Oxford University Press, 2016), pp. 186, 190.

${ }^{10}$ Ibid., pp. $183 f f$.

${ }^{11}$ Cannon, Making of Chaucer's English, p 160.

${ }^{12}$ Ibid., p. 160. On this point I would query the extent to which the lexicographical history has taken account of the all the administrative text available.
} 
But to reiterate, if we want to gain access to the written texts which were the most accessible to the greatest number of people, and therefore if we want to understand how medieval English vernacular writings influenced people's interpretation of the world in which they lived (their formation of 'communities of interpretation' in other words), we need (also) to look to administrative documents. We also need to consider popular religious literatures, the works of religious instruction such as the catechetical writings available in that earliest library known as the parish church. Those are not prioritized here but they are considered in Paula McQuade's article in this Dialogic Special Issue. For all these reasons, the administrative legal document known as the last will and testament forms the focal textual example for this article.

Thousands of wills survive for all areas of England, for men and women (mainly widows ${ }^{13}$ ), and from a wide social spectrum including very many people of what has often been described as 'the middling sort' - such as townspeople, merchants, yeomen and prosperous peasants. Although wills made during the century c.1450-1550 represent people from a broad social spectrum, the poorest people would not have been in a position to create a written document, mainly because of its cost and the relative lack of items to bequeath. ${ }^{14}$ Employing the last will and testament to

\footnotetext{
${ }^{13}$ On the greater freedom of widows to express their individual interests, see Robert Lutton, Lollardy and Orthodox Religion in Pre-Reformation England: Reconstructing Piety (London: The Boydell Press, 2006), pp. 51-53.

${ }^{14}$ Recent studies of the will as evidence for people's lives have tended to gravitate towards people of higher status see e.g. Susan James, Women's Voices in Tudor Wills, 1485-1603: Authority, Influence and Material Culture (Farnham: Ashgate, 2015). On the presupposition that poor people did not leave wills, see Claire Cross, 'Northern
} 
understand more about people's lives, literacy and communities of interpretation may seem ironic because it is a document made in consideration of death. But in fact, late medieval wills are vibrant sources of information about people's life experiences, as well as their hopes for the future. Wills made by people of all statuses give us access to the tenor of their religious beliefs, they demonstrate the will maker's loyalty to places of current or past residence, their occupational identity and status, and their affiliation to cultural groups. They also detail wishes for the prosperity and health of close family and for the wider networks of friends, family, and kin who have been important during their lifetime and who they hope will continue to play a part in the remembrance of their own lives and in the success of their families. ${ }^{15}$ Across the chronological range c.1380-1540, a typical last will and testament document would begin with the 'testament' which is the declaration of spiritual affiliation and identity, and then proceed with the 'will' which is the legal instrument for distributing heritable wealth including built property and agricultural land. Testaments generally identified the name and occupation of the testator, their place of residence, wishes for burial, and affiliation to saints and other religious groups such as fraternities. Some Women in the Early Modern Period: The Female Testators of Hull and Leeds, 15201650', The Yorkshire Archaeological Journal 59 (1987), 83-94 (p. 83).

${ }^{15}$ For a detailed consideration of the valuable evidence that wills provide for the construction of identity, see Elisabeth Salter, Cultural Creativity in the Early English Renaissance: Popular Culture in Town and Country (London: Palgrave, 2006). On wills as repositories of memory, see Judith S. W. Helt, 'Women, Memory and Willmaking in Elizabethan England', in The Place of the Dead: Death and Remembrance in Late Medieval and Early Modern Europe, ed. by Bruce Gordon and Peter Marshall (Cambridge: Cambridge University Press, 2000), pp. 188-205, esp. 189, 198. 
testaments specifically do not mention saints and other elements associated with medieval catholic piety, perhaps to signal specific types of religious belief, maybe heterodoxy, (and from the 1520s absence of reference to the trappings of medieval Catholicism becomes less unusual). ${ }^{16}$ The testament also often includes some gifts of items and money to religious institutions as well as to family and kin - these are often small items demarcated as precious by being mentioned in this section of the document. The will section details the testator's wishes for how his/her property and land will be distributed, and often uses phraseology from other documentation such as charters and deeds in which the conditions of renting, leasing and ownership are specified. The document finishes with a declaration that the text represents a faithful account of the testator's wishes, and a list of the witnesses and those who will be executors.

Wills are a major source of evidence for the ways that people used text to construct their communities, using official institutions such as parish church, guild, and family including kin and extended kin networks like Godparent-hood, as well as informal networks and associations such as reading networks, and communities of belief and interpretation that stood outside the immediate parameters of religious orthodoxy. ${ }^{17}$ Most wills are written in Latin until about 1480; more are in English

${ }^{16}$ On the rise of 'parsimonious piety', see Lutton, Lollardy and Orthodox Religion, pp. 55-63.

${ }^{17}$ See, for example, Peter Heath, 'Urban Piety in the Later Middle Ages: the Evidence of Hull Wills', in The Church, Politics and Patronage in the Fifteenth Century, ed. by Barrie Dobson (Gloucester: Alan Sutton; New York: St. Martin's Press, 1984), pp. 209-34; Robert Lutton, 'Godparenthood, Kinship and Piety in Tenterden, England 
after that date. When dealing with fifteenth- and sixteenth-century lives and specifically for this article people's encounters with the written word, the details available in wills are so valuable that it is important to appreciate just how much such documents can add to our knowledge, even though the surviving records do not provide a full picture because much has been lost. In addition, it is important to remember that many of the documents survived because they were copied into the large volumes known as Bishops' Registers. When a handwritten document is copied, there is the possibility that the 'scribe' might have made changes, or omitted sections, or misread particular words or phrases. Moreover, testators most often dictated wills to an amanuensis; such a procedure can lead to a slippage between what was dictated and what was written. These are factors always to bear in mind when reading wills. Although issues of method and interpretation have often been discussed in the past, ${ }^{18}$

1449-1537', in Love, Marriage and Family Ties in the Later Middle Ages ed. by Isabel Davis, Miriam Mueller and Sarah Rees Jones (Turnhout: Brepols), pp. $217-$ 234.

${ }^{18}$ On concerns about the role of scribal mediation in wills, see Clive Burgess, 'Late Medieval Wills and Pious Convention: Testamentary Evidence Reconsidered' in Profit, Piety and the Professions in Later Medieval England, ed. by Malcolm A. Hicks (Stroud: Sutton, 1990), pp. 14-33. For a full consideration of the methodological issues associated with using the last will and testament (including the case for their use as documents expressing individual views), see Salter, Cultural Creativity, pp. 1-25. See also James, Tudor Wills, 'Introduction’, pp. 1-12. 
the question of the reliability of wills as evidence does not need to undermine our use of this valuable source. ${ }^{19}$

The last will and testament is formulaic but also reveals individual or personal wishes. I argue that testators and testatrixes deployed last will and testament documents to assert or define these elements of their lives, rather than simply to report or record them - in other words, will makers enter a dialogic relationship with the legal language and formulaic requirements of the will. Wills, therefore, provide valuable details about individuals' perceptions of, and aspirations for, their own lives including the ways that they used this textual medium to construct and represent their communities of interpretation. In taking this approach to this type of historical document I have been influenced by the work of Nathalie Zemon Davis, Fiction in the Archives, which focuses on a different form of historical document but one which has an equivalent prevalence and social reach as the will document. ${ }^{20}$ Zemon Davis's sources are the Pardon Letters of sixteenth-century France and she insightfully demonstrates the varying ways that the deposition narratives used in these documents are manipulated to employ specific conventions of storytelling. Using the evidence of draft depositions (where they survive), she is able to show the consistency between

${ }^{19}$ These ideas were first articulated at length in Salter, Cultural Creativity; and Salter, 'Some Differences in the Cultural Production of Household Consumption in Three North Kent Communities, c. 1450-1550', in The Christian Household in Medieval Europe, 850-1550: Managing Power, Wealth and the Body, ed. by Cordelia Beattie, Anna Maslakovic, and Sarah Rees Jones (Turnhout: Brepols, 2003), pp. 391-407. ${ }^{20}$ Nathalie Zemon Davis, Fiction in the Archives: Pardon Tales and their Tellers in Sixteenth Century France (Stanford: Stanford University Press, 1987). 
the original written record of deponents' oral testimonies (and these may be letters written by or on behalf of the deponent) and the version of the narrative that is brought to the attention of the court. ${ }^{21}$ In so doing, she shows that scribes sought to preserve the original vocabulary and syntax used by the deponent. This is helpful in proposing an analogous situation with the will such that the scribe seeks to maintain the original request (given orally in the first instance), and we can extrapolate from this to the point at which the will is copied into the Bishop's register to suggest that the scribe would continue to maintain the particular linguistic forms used originally by the testator.

The scenario elucidated by Nathalie Davis helps to explain why quite colloquial or personal sounding descriptors are used for particular items in a will document. These are particularly noticeable in Latin texts that use vernacular (English) phrases to give heightened personal relevance or descriptive detail. For example in the Latin will of merchant widow Agnes Bedford, made in 1459, we find this bequest: 'meam zonam nigram vocatur Cristenynge gyrdell barred through oute et deauriat[?]... di dozen coclia cum akehornes' ${ }^{22}$ The girdle (zona) is qualified in English by the fact that it is called (vocatur) 'christening girdle' and its decorative content (probably silver bars) is identified in part of the English description giving it a particular resonance of the testatrix's original description. In the description of the decorative acorns on the silver spoons I think we can almost hear the pronunciation in

${ }^{21}$ Ibid., pp. 22-4.

${ }^{22}$ Agnes Bedford (w 1459; d 1459), The Borthwick Institute, University of York 2/418r-419r: "my black girdle called a Christening Girdle barred throughout and gilded with silver, half a dozen spoons with acorns'. 
the spelling of 'acorns'. Both of these examples from one bequest give an indication of the ways we might gain access to the oral moment (or oral 'text' - which I will discuss later) in the creation of the last will and testament document.

Nathalie Davis used her extensive corpus of evidence, and her intensive examination of it, to demonstrate how the deponents constructed their stories according to a set of stereotypes or conventions of behaviour. So, in other words, Davis identified that deponents knowingly performed a role expected by society in order that their plea can be 'heard'. Sometimes they also manipulated those conventions and expectations if the impact of this might lead to the positive outcome (i.e. the pardon) that they required. ${ }^{23}$ In her recent discussion of the textual evidence from the medieval court of Chancery, Cordelia Beattie has identified that the 'petitioning subject' is constructed in the process of making the petition for the court of law. For Beattie, the petitioning subject is neither a revelation of the person nor a fictive persona, it is a textual construct for the specific purposes of the court petition. Understanding this, she suggests, helps us to 'make a link between the text and the lived life' ${ }^{24}$

My argument about the significance of the will document in society is predicated upon the idea of the extensive involvement of communities with the wills of the people they lived among. The treatise on will-making produced by the lawyer

${ }^{23}$ Davis, Fiction in the Archives, Chapter 1 (and passim).

${ }^{24}$ Cordelia Beattie, “"Your Oratrice”: Women's Petitions to the Late Medieval Court of Chancery,' in Women's Agency and the Law 1300-1700, ed. by Bronach Kane and Fiona Williamson (London: Pickering and Chatto, 2013), pp. 17-30 (p. 22). 
Henry Swinburne in the late sixteenth century assists with providing the context of will making here. ${ }^{25}$ In this treatise, there is considerable detail about who may be a witness to a will and how they are to do this. Swinburne outlines that the witnesses must be present to verify and sign that the testator's wishes have been honestly recorded, and that witnesses can be people of low means (such as household servants) as well as women (despite their 'frail character'). ${ }^{26}$ The Briefe Treatise also gives details and advice about the production of a nuncupative will (one delivered orally) with a key issue being that the will must be plainly spoken in either formal or 'vulgar' words to avoid ambiguity. Here we might assume that 'vulgar' refers to the English tongue, from the Latin, vulgariter. Being written in the late sixteenth century this

${ }^{25}$ Henry Swinburne, A briefe treatise of testaments and last willes very profitable to be vnderstoode of all the subiects of this realme of England, (desirous to know, whether, whereof, and how, they may make their testaments: and by what meanes the same may be effected or hindered,) and no lesse delightfull, aswell for the rarenes of the worke, as for the easines of the stile, and method: compiled of such lawes ecclesiasticall and ciuill, as be not repugnant to the lawes, customes, or statutes of this realme, nor derogatorie to the prerogatiue royall. In which treatise also are inserted diuers statutes of this land, together with mention of sundrie customes, aswell general as particular, not impertinent thereunto: besides diuers marginall notes, and quotations not to be neglected, especially of Iustinianists, or young students of the ciuil law: vvith two tables, the one analyticall ... the other alphabeticall ... By the industrie of Henrie Swinburn, Bachelar of the Ciuill Lawe. , London : Printed by Iohn Windet, 1590 [i.e. 1591] STC (2nd ed.) / 23547, accessed via Early English Books Online [http://eebo.chadwyck.com/search, accessed February $\left.15^{\text {th }} 2018\right]$. ${ }^{26}$ Swinburne, Treatise of testaments and last willes, Chap 4. 
treatise was produced chronologically late for the consideration of medieval texts. However, it is referring to practices and customs that would have been established over centuries and therefore it is a valuable source of evidence for the theory of what ought to happen even if this does not always reflect the practice of what people actually did.

Medieval people's participation in the 'literate occasion' associated with the legal process of confirming a will document is central to my analysis of the pervasive cultural and aesthetic influence of this form of written (and oral) text in English medieval society. I am drawing here on the rethinking of the nature of literacy that has been influenced by anthropological approaches, such as Brian Street's proposed 'ideological model', which takes into account the cultural contexts of literacy. ${ }^{27}$ Street explains fully the distinctions, implicit in the ideological model, between 'literacy events' and 'literacy practices'. Literacy events, a term coined by sociologist Shirley Brice Heath, should be interpreted in relation to the 'larger sociological patterns which they may exemplify or reflect' ${ }^{28}$ Therefore individuals not actually literate themselves in 'literacy practices' might be part of the occasion (the event) in which literacy is used, for example when a will document is read out in front of witnesses or

27 Brian V. Street, Literacy in Theory and Practice, Cambridge Studies in Oral and Literate Culture (Cambridge: Cambridge University Press, 1984), pp. 94-125. See also for example Nicko Besnier, Emotion and Authority: Reading and Writing on a Polynesian Atoll, Studies in the Social and Cultural Foundations of Language, 17 (Cambridge: Cambridge University Press, 1995), on the appropriation of colonial literacy practices by the Nukulaelae people.

${ }^{28}$ Street, p. 125. 
a company of beneficiaries. This engagement with the written word may influence those individuals' cultural or aesthetic experiences as well as enable them to gain some basic reading ability. Orality and literacy are therefore very closely aligned in the experience of popular literacy in this period. This reminds us that medieval England is a culturally different or 'other' situation from the modern scenario in which, crudely put, there is mass-produced text, with proliferating ways of accessing writing in the digital age. Modern life in many parts of the world also confers greater anonymity in contradistinction to the 'face to face' communities of medieval society. These factors mean that there was relatively more investment in the 'life texts' of neighbours and community members in a medieval society than there is today.

To analyse the 'otherness' of medieval society, I find it useful to turn to anthropological analyses of 'other' places in which we can find some comparisons with medieval people's experiences. This is not to impose a pseudo-modern psyche onto the complex historical subject that is the medieval individual. Rather it is to gain some insights in terms of a nuanced understanding of cultural process by comparison with a society that might reflect some aspects of the medieval situation. ${ }^{29}$ In this instance, anthropology is helpful for understanding the ways that literate and oral culture intersect in communities that are less westernized, less urbanized, and engaged therefore in different processes of community formation that have resonance with English Medieval society. Karin Barber's recent work on oral and written culture, The Anthropology of Texts, Persons and Publics, provides very fruitful comparative

\footnotetext{
${ }^{29}$ For concerns about how anthropological models are used with historical subjects see, Raphael Samuel, 'Reading the Signs II: Fact Grubbers and Mind Readers', History Workshop, 33 (1992), 220-51 (p. 244).
} 
analysis for this discussion. She notes at the outset that it is a 'tricky, demanding and uncertain business' trying to attune oneself to the 'modes of composition and methods of interpretation by which people of other cultures constitute texts' ${ }^{30}$ This is a useful place to begin because it highlights a couple of key issues when working with late medieval popular literacy - firstly that it is 'tricky' and demanding and secondly that it does involve being attuned to the ways that a different culture perceived and used text - in other words that we should avoid seeking to impose modern western conceptions of literacy, or indeed community, onto our (medieval) subjects.

Barber's analysis of the close relationships between orality and literacy is extremely useful here. Her chapter on 'textual fields and popular creativity' explodes some of the conceptions we might have around the distinctions between oral and literate modes of communication. Using her approach we can refer to both literate and oral forms as 'texts'. This is very useful for thinking about the dialogic interactions between orality and literacy in popular cultures of the past (with regard to the role and impact of the will document). Barber, for example, notes that there is potential for oral genres such as foundation myths and popular history to be fixed compared to writing's requirement for continual ingenious efforts to preserve it in the same form. ${ }^{31}$ She also proposes that the act of listening is creative (i.e. productive of meaning) similarly to the way that the act of writing is creative, and therefore that processes of reception (and delivery) associated with orality have equivalence with activities

${ }^{30}$ Karin Barber, The Anthropology of Texts, Persons and Publics: Oral and Written Culture in Africa and Beyond (Cambridge: Cambridge University Press, 2007), p. 201. ${ }^{31}$ Ibid., e.g. p. 201. 
associated with writing and reading written text. ${ }^{32}$ These points immediately cause us to question a common (mis)conception about the relative fixity of the written word in comparison to the fluidity of the oral record.

Barber also advocates that in order to understand more about language choice and the meanings of particular words and phrases in any text, elite literatures or popular tales, we should look at the ways that verbal forms emerge from everyday life. This is a view of creativity 'from the bottom up'. It enables popular genres of written and oral 'texts' to be considered in the 'same frame' as each other privileging neither. Barber calls this the process of 'entextualisation' ${ }^{33}$ It is useful to look at some examples from the last will and testament evidence to see how this kind of analysis might be put into practice.

Processes of entextualisation can be detected in slightly different ways in the Latin wills which introduce snippets of vernacularity for the purposes of description or, in the English wills, which introduce personal parlance to the legal discourse. An example from an English will made in Kent is this pious request of Simon Godfrith in 1523:

Item I gyve for to be bestowyd for a ffygure of Jhu the quantity of a man Stanyd in a clothe And to be naylys ypon a borde w+ my name wretyn in hyt to be sett in the lyfte side of the hyghe alter in the churche of nyttlystede $\mathrm{xxs}^{34}$

\footnotetext{
${ }^{32}$ Ibid., p. 210.

${ }^{33}$ Ibid., pp. 68-76, 207.

${ }^{34}$ Centre for Kentish Studies, DRb Pwr 7/270.
} 
A further example from English will texts shows the ways that generic and personalized descriptions can be found in one bequest. This example is from the wills of Agnes Newark, widow, of Greenwich (1511). She bequeaths to her kinswoman Anne Cook a chamber, in other words a room, in terms of the generically expected contents of that room but excludes certain items from the bequest:

One chamber over my head whole, complete with bankers, cushions, chests and all in the chamber except my gowns one table cloth of diaper one towel diaper twelve napkins of diaper one goblet of silver six best spoons, a maser with a prente [printed decoration] and one salt of silver ${ }^{35}$

Both of these examples introduce personalized description or personal parlance in order to convey the intricacies of the bequest in a way that is intended to make sense to the individuals performing the wishes after the death of the testator. The use of English words for the christening girdle and the acorns in the Latin text of Agnes Bedford's will (discussed earlier) is one example of the ways that use of the vernacular brings additional nuance to the Latin text. Another example is found in the Latin will of Agnes Patrington of Hull (1474) who left to her son, the chaplain Thomas Sproxton, 'unum craterem stant \& cooptorem cum rosie \& un $\underline{u m}$ falconis super lez knoppes. ${ }^{36}$ Agnes also bequeathed two beds described in this Latin text as 'arrasbeds'. Patrington's example demonstrate the use of 'Franglais' for the knobs on

\footnotetext{
35 Centre for Kentish Studies DRb Pwr 6/91.

${ }^{36}$ Agnes Patrington (w 1474; p 1482), Borthwick 5/64r. "a standing bowl covered with roses and a falcon on top of the handles."
} 
the spoons as well as the ways that foreign place names, in this case Arras in France, could be used and made English in order to denote a specific style of object. Andrew Butcher discusses a similar scenario for the appropriation and use of English words in officially Latin administrative documents in his consideration of "vernacular behaviour' in the administrative literature of Canterbury Cathedral Priory. ${ }^{37}$ Butcher's insightful and careful study of the 'Views of Account' records provides extensive evidence, in some detail, for the interplay of vernacular and Latinate forms, and the 'community of writers, readers, speakers, listeners and witnesses involved' in the processes of textual production. ${ }^{38}$ The purpose of raising this point, here, is as a reminder that accessing everyday speech patterns, 'everyday acts of entextualisation' as Barber would describe them, allows us to 'widen our field of vision to include forms, genres and generative processes often overlooked or excluded when the object of the study is 'literature' conventionally defined' ${ }^{39}$ Barber's point here helps to emphasise the value of considering administrative documents in order to understand more about the general context of the developing English vernacular, including English literatures, in late medieval England.

\footnotetext{
${ }^{37}$ Andrew Butcher, 'Textual Production and Vernacular Behaviour: Locating a Fifteenth Century Administrative Court Book', in Vernacularity in England and Wales, c 1300-1550, ed. by Elisabeth Salter and Helen Wicker (Turnhout: Brepols, 2011), pp. 295-323.

${ }^{38}$ Butcher, p. 298. See also Ian Johnson, 'Afterword', also in Vernacularity in England and Wales, c 1300-1550, for his comment on the nuances of Butcher's analysis pp. 325-35 (p. 304).

${ }^{39}$ Barber, p. 212.
} 
But here is one of the perennial issues that those of us who study societies from the past face: it is all very well using this approach in ethnography where one might record the speech of individual subjects from a society and then assess the ways that their speech patterns relate to written texts. But what if we can no longer directly hear the speech of those people who lived? When studying the late medieval era we cannot refer to recordings of speech. Can we extrapolate back from this point to gain access to people's speech patterns? I would suggest that examples from the last will and testament give us this possibility, and that Latin wills which use vernacular forms for specific descriptive words (as shown above) give us particular insights into the speech patterns in use during the oral testimony of the testator. Perhaps here is a point where the surviving English literature of late medieval England may act as a useful comparator. In Chaucer's Canterbury Tales, for example, we might take the Reeve's appropriation of scripture that follows his interjection about the Miller's use of 'cherle's termes'. Chaucer in the voice of the Reeve uses 'stalke' (a piece of straw) for the biblical speck of sawdust and the rhyming 'balke' (a beam) for the plank of Matthew 7.3..$^{40}$ The two words are chosen to rhyme, and they also perhaps give us insight into common parlance for these types of matter.

When thinking more about the ways that people formed their communities of interpretation through their engagements with written and oral texts, we are asking this 'tricky' question: how did involvement with either written or oral texts inform medieval people's perceptions of themselves and the world around them? This is an area of inquiry that is open to many questions that are familiar to those who research 'process' (such as the nature and formation of popular ideas and beliefs) in past

\footnotetext{
40 Chaucer, 'The Reeve’s Prologue', ll. 3919 and 3920.
} 
cultures. How can we ever know what motivated people or how they perceived the world? How can we ever know what people really thought and believed? How can we interpret the impact of involvement with written or oral texts, and the uses of English in this context?

Whilst definitive answers to these questions are not possible, I propose that we can gain some insights by exploring the dialogic interaction between orality and literacy as evidenced by administrative documents such as the last will and testament. This enables us to understand more about cultural processes such as the ways that people formed their interpretive communities. To help in this endeavour, I will turn to one 'inspiration' that, I feel, aids our understanding of the dialogic entextualisation process that occurs when a last will and testament is being produced by a medieval testator (and when it is being interpreted by a cultural or literary historian). Understanding the dialogic nature of entextualisation enables greater understanding of the impact on medieval individuals of making a will, and in particular the ways that will-making could inform their views of themselves and the world around them. The 'inspiration' to which I refer derives form the work of Johannes Fabian who has written extensively and formatively about popular culture and how we may use our evidence. Of particular significance for this article is his exposition of the ways that a 'dialogic encounter' is key to the ethnographic process. ${ }^{41}$ Specifically in this instance, I refer to Fabian's essay exploring the intersubjective process of creating objective

\footnotetext{
${ }^{41}$ Johannes Fabian and K. M. Tshimbumba, Remembering the Present: Painting and
} Popular History in Zaire (Berkeley and London: University of California Press, 1996) 
knowledge. ${ }^{42}$ Here Fabian reviews the development of anthropological study (and the ways it has intersected with other key disciplines and their paradigm shifts) - in the conceptual milieu of 'the linguistic turn' in anthropology. A key element in the proposition of Fabian's essay is its critique of the positivist empiricism in which the analysis of a phenomenon seeks to treat that phenomenon as a fixed object (rather like a fly in amber). A 'postitivst-empiricist' approach reports on that phenomenon/fixed object as if there were no interchange between that object and the analyst (the analyst being the ethnographer in Fabian's case). In other words it is as if there were no 'dialogic' process in which the 'object' speaks and the reporter/ethnographer listens as s/he writes. The ethnographer/reporter is the 'literary historian' in my case. ${ }^{43}$

Fabian's proposal about the 'intersubjective' process of knowledge construction moves past the (necessary) stage in the debate in which there was a call for all knowledge to be understood as subjective. ${ }^{44}$ Another way of looking at this is to insist that there is no such thing as 'objective' knowledge. The 'denial of objectivity' phase remains a significant stage in the debate, which has sensitized us to issues of interpretation. An important set of voices in the development of this debate are those represented in the collection brought together by anthropologists James Clifford and George Marcus, Writing Culture. Here, for example, James Clifford traces the developments in ethnographic writing that signaled a refusal to accept

42 Johannes Fabian, 'Ethnographic Objectivity: From Rigor to Vigor', in Anthropology with an Attitude: Critical Essays (Stanford: University of Stanford Press, 2001), pp. 11-32.

43 Ibid., p. 15.

${ }^{44}$ Ibid., p. 19. 
ethnographies as presenting objective reality. ${ }^{45}$ In this 1986 publication, Clifford uses the term 'cultural poetics' to reflect the 'interplay of voices, of positioned utterances' which constitute a piece of ethnographic writing. ${ }^{46}$ Clifford's emphasis on the implications of appreciating that we construct our interpretations from dialogues remains significant here - he notes that the dialogic approach: 'locates cultural interpretations in many sorts of reciprocal contexts, and it obliges writers to find diverse ways of rendering the negotiated realities as multi-subjective, power laden, and incongruent. ${ }^{47}$

A key criticism that Fabian raises of the 'everything is subjective' position is that it gives potential for everything to be endlessly relativist such that we are ultimately unable to posit any findings. Fabian has moved the debate onwards, therefore, to his assertion that the creation of knowledge (the interplay between the object of study and the reporter/ethnographer or indeed the 'historian') is an 'intersubjective process'. The finale of his argument, therefore, is that this inter-subjectivity is a condition of the construction of all knowledge (and that includes what we might call 'objective' knowledge). ${ }^{48}$

45 James Clifford, 'Introduction', in Writing Culture: The Poetics and Politics of Ethnography, ed. by James Clifford and George Marcus (Cambridge, MA: Harvard University Press, 1986), pp. 1-15 (pp. 11, 14).

${ }^{46}$ Ibid., p. 12.

${ }^{47}$ Ibid., p. 15.

${ }^{48}$ Fabian, 'Ethnographic Objectivity', pp. 26-32. 
Fabian's analysis of the intersubjective process of knowledge construction is valuable for an investigation of the impact of the last will and testament on what might be termed the 'mentalite' of medieval people. It is helpful because it assists with elucidating the dialogic processes that occur when engaging in historical reconstruction from archival documents, as well as sensitizing us to the dialogic process that had already occurred in the production of that text. As already noted, we know that the case is somewhat different with the cultural historical study of past societies than with ethnography of current peoples, as one is unable to engage directly with the speaking subject. ${ }^{49}$ With archival material, and with the will text specifically, we need to go through a reverse process (or an 'unpicking') in the first place to get to the wishes and hopes that were expressed at the deathbed or in consideration of death. This is because most wills were originally oral testimonies whereas in the form we encounter them they are already subjected to a specific form of 'entextualisation' by the scribal process of recording that I described briefly earlier in this article. Moreover, this entextualisation occurs within the formulaic constraints of this legal document, in compliance with a set of customary rules and regulations.

The necessary 'unpicking' is entirely connected with the issues raised earlier in this article about the advantages of dealing with a formulaic text: hints of the speaking or writing subject (somewhere between the real individual and the textually

${ }^{49}$ On potentials for misunderstanding see also Johannes Fabian, 'Ethnographic Misunderstanding and the Perils of Context', in Anthropology with an Attitude, pp. 33-52 (pp. 38-9). Here Fabian identifies that transcribing the oral record in the field is not always simple because of the possibilities for misconstruing or mistranslating the language being used. 
constructed fictive persona) can be recovered in the interstices of the formulaic text if one is attentive to the nuances of individual wish or personal detail that occur in the non-standard moments and the snippets of narrative detail often given in a will text. ${ }^{50}$ For example, in the English will of Isabel Wylton (1486) of Hull, where she bequeaths to Johannet Scoles, alongside various silverware including a maser cup with a print of St George in the bottom, a number of more practical items including brass pots and iron spits kept in the chimney one of which items, a 'shorte footed pott', is described alongside 'the pott we made our mete in' ${ }^{51}$ Here, Isabel provides an evocative reference to shared occasions of eating and domestic activity which stand out from the formulaic requirements of which pot is given to whom. Isabel Wylton gives stories for other items bequeathed in her will too, for example to her daughter, Marion, she bequeaths one best coffer, 'the best that she woll chose of three'. She also gives to Marion the harness (girdle) that was her father's (which he had given to Isabel). And in a bequest to another woman, Agnes Porter, Isabel bequeaths a pair of beads 'which Marion leves untaken'.

The proposal for interpretation of this material to be an inter-subjective dialogue requires an approach to the evidence which is sensitized to the processes by which knowledge is being constructed and created through the will document. This includes taking full consideration of breaks from the formula which betray something of the medieval individual's personal view and maintaining sensitivity to these features in order to think oneself inside the situation presented by our medieval testator (and entextualised by him or her and by the legal process rather like the

\footnotetext{
${ }^{50}$ For a recent discussion of the methodological issues here, see Beattie, pp. 18-20.

${ }^{51}$ Isabel Wylton (w June, 1486; p 1487), 5/297v-98r.
} 
examples given by Natalie Zemon Davis and Cordelia Beattie). The outcome of this style of analysis is that we might gain an enhanced understanding of what it is that the medieval testator wanted to, or did actually, say, and why it mattered to say it that way. We cannot remove our own selves from the process of interpretation and it would be foolish to claim that we could, which is why the idea of the dialogic encounter is so helpful here. My sense of what any medieval individual is 'trying to say' is entirely formed through dialogic encounter with my own self and my own anticipations and preconceptions. This is not a lesser way of interpreting historical evidence because it acknowledges the dialogic encounter I engage in, it is simply a more honest way of presenting what always happens in the process of historical reconstruction.

The proposition of this article is that we can use administrative documents such as the last will and testament to understand more about the construction of communities of interpretation. Moreover, examining the use of 'English' can enhance our understanding of medieval people's communities of interpretation, especially if the interplay between orality and textuality is understood as a dialogic process of 'entextualisation', and we are prepared to appreciate our own dialogic engagement with the evidence as literary-historian-ethnographers.

A clear case can be made for the last will and testament's role in the formation of a 'speech community' because the will will be read out when it is 'performed' at some point in the legal process of enacting the wishes of its testator. The role of the English language text in this performance process (for Latin wills as well as for those originally written in English) is important. The detailed descriptions of the material 
items that form heirloom items are used creatively by their testators to construct their identity as individuals and as members of various communities of interpretation. ${ }^{52}$ Choices about language use are significant throughout these bequests. Choices about vocabulary are highlighted by the use of English words in an otherwise Latin document as in the case of Agnes Bedford's acorns. And personal narrative information about individual items as with Isabel Wylton's 'shorte footed pott' gives us a hint of the spoken language of the medieval testator. As a final example, take the use of the English phrase 'drynke depe' in the Latin will text of John Rollaston of Beverley (1458).

Item lego Margarete Trimnas sororis mee unum ciphum argendem cooptum cum hac racionis inscribpsit in cooptoris eiusdem drynke depe \&c

'Drynke depe', describing the inscription on the silver cup, gives us a sense of the moments when only the vernacular will do, and also hints at the deeper cultural issues of how proverbial English may have been inscribed into the heart of medieval people's experiences of their precious heirloom goods.

I suggest that it may be helpful to cross-refer to self-conscious performances of common speech that are found in medieval literary writers such as Chaucer and his contemporaries in order to augment our understanding of the ways that medieval people made meaning through oral and literate texts. Certainly, if we are to understand more about the development of the English language we need to

${ }^{52}$ See Salter, Cultural Creativity, for detailed attention to the role of the will in the construction of identity. 
incorporate the evidence of administrative documents alongside the literary texts and the foundational myths that have surrounded them. And, I suggest, we need to think more about the dialogic processes of knowledge construction that are at play for both the production of these texts and our analyses of them. 